\title{
The limits of religious freedom in Indonesia: with reference to the first pillar Ketuhanan Yang Maha Esa of Pancasila
}

\author{
Abdul Mu'ti \\ UIN Syarif Hidayatullah Jakarta \\ E-mail:masmukti47@gmail.com
}

\author{
Ahmad Najib Burhani \\ The Indonesian Institute of Sciences (LIPI) Jakarta \\ E-mail:najib27@yahoo.com \\ DOI: 10.18326/ijims.v9i1. 111-134
}

\begin{abstract}
Surveys and researches have indicated various factors leading to or instigating the rise of religious intolerance in Indonesia after the Reformasi in 1998. This study, however, aims to see intolerance and discrimination as something embedded in Indonesian ideology, i.e. Pancasila, which seems to be lacking in previous studies, including the studies on the connection between Pancasila and discriminative regulations implemented is several districts and provinces in Indonesia. The questions dealt with in this paper are the following: Why did religious radical groups able to exert their influence to the government and moderate Muslim majority in treating minorities? What are, if any, the constitutional and legal limits of religious freedom in Indonesia? This paper aims to scrutinize constitutional and legal documents, including the first pillar of Pancasila, to find their shortcomings in protecting religious freedom. This
\end{abstract}


paper argues that Pancasila has set Indonesia into religiously monotheistic state, which provided the government the necessary tool to force non-theistic, polytheistic, and non-monotheistic religions to modify their theological beliefs in order to be accepted as recognized or official religions. Pancasila also justifies the existence of favoritism to certain religions deemed fit to this ideology.

Berbagai survei dan penelitian telah menunjukkan berbagai faktor yang menyebabkan atau memicu bangkitnya intoleransi beragama di Indonesia setelah Reformasi tahun 1998. Penelitian ini ingin melihat intoleransi dan diskriminasi sebagai sesuatu yang secara tak sadar tertanam dalam ideologi Indonesia, yaitu Pancasila. Tema ini tampaknya kurang menjadi perhatian dalam studi sebelumnya, termasuk studi tentang hubungan antara Pancasila dan peraturan diskriminatif yang diterapkan di beberapa kabupaten dan provinsi di Indonesia. Pertanyaan yang dibahas dalam artikel ini diantaranya adalah: Mengapa kelompok-kelompok radikal keagamaan dapat mempengaruhi pemerintah dan mayoritas umat Muslim yang moderat dalam bersikap terhadap kelompok minoritas? Apa, jika ada, batasan konstitusional dan legal kebebasan beragama di Indonesia? Artikel ini bertujuan untuk meneliti dokumendokumen konstitusional dan hukum, termasuk pilar pertama Pancasila, untuk menemukan kekurangan dalam melindungi kebebasan beragama. Artikel ini berargumen bahwa Pancasila telah menetapkan Indonesia menjadi negara monoteistik religius, yang memberikan pemerintah piranti yang diperlukan untuk memaksa agama-agama non-teistik, politeistis, dan non-monoteistik untuk memodifikasi keyakinan teologis mereka agar diterima sebagai agama yang diakui atau resmi. Pancasila juga membenarkan keberadaan favoritisme untuk agama-agama tertentu yang dianggap cocok dengan ideologi ini.

Keywords: Pancasila; Religious freedom; Theology; Favoritism; Constitution 


\section{Introduction}

After the Reformasi 1998, as reported by a number of studies ${ }^{1}$, the number of incident of religion intolerance in Indonesia has been increasing. The closing of Yasmin and Philadelphia Churches; the attack and displacement of Shi' ite community in Sampang; the recurrence attack and discrimination towards Ahmadiyya community in several places in Indonesia are among the examples. Attack, discrimination, other kind of violation of religious rights of Ahmadiyya and Shi'ite community even still continue sporadically until today. The most obvious symbols of this discrimination are Transito shelter in Mataram, West Nusa Tenggara and Puspa Agro shelter in Sidoarjo, East Java. In Transito, around 240 displaced Ahmadis have been living in two halls since 2006. Each family has been living poorly in $2 \times 3$ meter room separated with curtain from other family. In Puspa Agro, around 200 Shi' ite members from Sampang Madura have been living there since 2012. These two places can be called "living monuments" of discrimination and intolerance towards religious minorities. Before settling down and solving the case of Ahmadiyya in Transito and Shi'ah Sampang in Puspa Agro, it seems to be difficult to say that the government has done enough to protect the rights of religious minorities. Before removing these two monuments, the negative report of religious life in Indonesia will probably appear repetitively every year.

Some scholars ${ }^{2}$ indicated that it is the weakness of law enforcers,

\footnotetext{
${ }^{1}$ Melissa Crouch, "Religious Regulations in Indonesia: Failing Vulnerable Groups", Review of Indonesian and Malaysian Affairs, Vol. 43 No. 2 (2009), 53-103; Jessica Soedirgo, "Informal Networks and Religious Intolerance: How Clientelism Incentivizes the Discrimination of the Ahmadiyah in Indonesia”, Citizenship Studies, No. 22 No. 2 (2018), 191-207; Zainal Abidin Bagir, "Advocacy for religious freedom in democratizing Indonesia", The Review of Faith $\mathbb{E}$ International Affairs, Vol. 12 No. 4 (2014), 27-39.

${ }^{2}$ Jacques Bertrand, Nationalism and ethnic conflict in Indonesia, Cambridge, UK: Cambridge University Press, 2004; Gerry Van Klinken, Communal violence and democratization in Indonesia Small town wars, London: Routledge, 2009; Ashutosh Varshney (ed.), Collective violence in Indonesia, Boulder: Lynne Rienner Publishers, 2010.
} 
particularly the police, judge, and government apparatus, that contributed significantly to the occurrence of intolerant acts in several years and places in Indonesia. Some people directed their attention specifically to the existence of groups commonly called "vigilante groups" such as the FPI (Front of Defenders of Islam) as the one that mostly responsible for those acts of religious intolerance. One of the key questions to those groups is "Why are religious radicals, who represent less than one percent of the population, having such success in changing Indonesia from a nation that has long based its identity on religious, cultural, and ethic pluralism to one facing growing and, in many levels, state-sanctioned intolerance?"3 Is it true that they have successfully changed the contour of religiosity in Indonesia? There are also some scolars who try to see inter and intra religious conflicts in Indonesia from international perspective by connecting these conflict and the Middle East conflicts or the global rise of radicalism; they have certain repercussion in the rise of conservatism and hostility towards those considered as deviant or foreign or simple different other. Oddly enough, there are also group of people, such as the LPPI (Institute for Islamic Study and Research), who blame the victims by saying that it is the aggressive and provocative activities of religious minorities that trigger the attacks to these religious communities. ${ }^{4}$

The above studies have contributed in explaining the causes of religious intolerance in Indonesia, but there is something to be missing; no study tries to see the intolerance as an inherent problem of Indonesian system

${ }^{3}$ Mary E. McCoy, "Purifying Islam in Post-Authoritarian Indonesia: Corporatist Metaphors and the Rise of Religious Intolerance”, Rhetoric Ë Public Affairs, Vol. 16, No. 2 (2013), 275-315.

${ }^{4}$ Robin Bush and Budhy Munawar-Rachman, "NU and Muhammadiyah: Majority Views on Religious Minorities in Indonesia", in Johan Saravanamuttu and Bernhard Platzdasch (eds.), Religious diversity in Muslim-majority states in Southeast Asia: areas of toleration and conflict. Singapore: ISEAS, 2014, p. 30; Ahmad Najib Burhani, "Fundamentalism and Religious Dissent: the LPPI's Mission to Eradicate the Ahmadiyya in Indonesia." Indonesia and the Malay World. Vol. 44 No. 129 (2016): 145-164. 
of government, a problem that is embedded in its ideology of Pancasila and its constitution. There is no study that try to see the connection between Pancasila or Indonesian Constitution and discriminative regulations implemented in several districts and provinces in this country. ${ }^{5}$ In the context of the protection of religious freedom, most of academic and advocacy studies see that there is no problem related to Indonesian constitution and also the ideology of Pancasila. They come to conclusion that Indonesian 1945 constitution and ideology of Pancasila have strongly guaranteed religious freedom as clearly stated, for instance, in the Article $28 \mathrm{E}$ and 29.

In contrast to the above studies, this article intends to see the relation between Indonesian constitution, which contains the ideology of Pancasila, and the emergence of discriminative regulations and acts of intolerance in Indonesia. The questions that will be dealt with are the following: Is there any holes in the constitution that inspire or make possible for the issuance of discriminative and intolerance regulations or bylaws in Indonesia? Based on the constitution, what are the limits of religious freedom? Are the limits inherently embedded in the constitution or are they merely from political interpretation of the constitution? What kind of limitation of religious freedom instigated by the constitution? This article argues that the basis and root of discriminative and

${ }^{5}$ Sita Hidayah $(2010 ; 2012)$ and Ismatu Ropi $(2016)$ try to make an initial effort to comprehend this issue. However, the conclusion of their studies show that this issue emerges as a consequence of different interpretation of the constitution and Pancasila. For the present author, it is a mild or soft or ambiguous conclusion. See Sita Hidayah, "Translating 'Ketuhanan Yang Maha Esa': An amenable religious ideology”, in Pancasila's contemporary appeal: Re-legitimizing Indonesia's founding ethos, eds. Thomas J. Conners, et. al., p. 239-254. Yogyakarta: Sanata Dharma University Press, 2010; Sita Hidayah, "The politics of religion: The invention of "agama" in Indonesia". Kawistara, Vol. 2 No. 2 (2012): 121-139; Ismatu Ropi, "Ketuhanan Yang Maha Esa, the State and the Politics of Religious (In)Tolerance: Understanding Contemporary Religious Life through Past Debates on the State-Religion Relationship," in Religion, Law and Intolerance in Indonesia, Tim Lindsey and Helen Pausacher (eds.), New York: Roudledge, 2016: 132-157. 
intolerant regulations and bylaws in Indonesia is embedded in the 1945 Constitution, particularly article 29 section one ("The state is based on Ketuhanan yang maha esa"), and the first pillar of Pancasila, Ketuhanan Yang Maha Esa.

\section{The first pillar of Pancasila: Ketuhanan Yang Maha Esa}

Pancasila, a combination of two old Javanese words Panca and sila that literally means five principles, is the national ideology or official philosophy of Indonesia state. ${ }^{6}$ In Indonesian constitution, this ideology is written in the preamble of UUD (Undang-undang Dasar) 1945.

Pancasila consists of five pillars or principles, namely: 1) Ketuhanan yang maha esa (Belief in the one and only god); 2) Kemanusiaan yang adil dan beradab (Just and civilized humanity); 3) Persatuan Indonesia (The unity of Indonesia); 4) Kerakyatan yang dipimpin oleh hikmat kebijaksanaan, dalam permusyawaratan perwakilan (democracy led by God's guidance and wisdom arising out of deliberations amongst representatives); and 5) Keadilan bagi seluruh rakyat Indonesia (Social justice for all Indonesian people).

Out of these five pillars, the longest debate among the founding fathers of Indonesia during and after the independence of this country in 1945 is the first pillar. The debate revolved around the wording and position of this pillar among other pillars. In Sukarno's draft of Pancasila, instead of becoming the first pillar, "belief in the one and only god" was the fifth pillar. The wording also did not incline to endorse monotheistic religion. It is only ketuhanan (belief in god), without any inclination towards monotheistic, non-theistic, or polytheistic religions.

\footnotetext{
${ }^{6}$ Because of the prominent place of Pancasila, there are two holidays related to this ideology: The birth of Pancasila day (Hari Lahir Pancasila) on June 1 and the Divine power of Pancasila day (Hari Kesaktian Pancasila) on October 1.
} 
The wording of Ketuhanan yang maha esa is actually also a revised version of the draft agreed upon by members of the drafting team of Indonesian philosophy, called Piagam Jakarta (Jakarta Charter). ${ }^{7}$ The wording of the first pillar of Pancasila in the Jakarta Charter is "Ketuhanan, dengan kewajiban menjalankan syari'at Islam kepada pemeluk-pemeluknya" (Belief in god, with the obligation for adherents of Islam to carry out the shari'a).

In the context of religiously plural society of Indonesia, the first pillar of Pancasila as written in Piagam Jakarta was felt by some Indonesian to be bias to Islam. As stated in the history of Pancasila, there was a call during the night before the declaration that some delegation from eastern part of Indonesia lobbied and met Muhammad Hatta, a member of the drafting team, and expressed the feeling of some Christians in the eastern part of Indonesia. They would not join Indonesian state that would be declared soon if there is no revision of the first pillar of Pancasila. Responding to this complaint, Hatta then lobbied some members of the drafting team, particularly the Islamist group, to revise the wording of the first pillar for the sake of unity of Indonesia. The wording of Ketuhanan yang maha esa is the final version agreed upon by the drafting team. From the process of drafting, the wording and position of each pillar are a political consensus and compromise of the founding fathers, usually seen as consisting of three main groups: nationalist, Islamist, and non-Muslims.

Some Muslim scholars often see that the final wording of the first pillar of Pancasila is a gift and sacrifice of Indonesian Muslims for the unity of Indonesia. By sacrificing the ideal political objective of Muslim politician at that time, the unity of Indonesia can be preserved. Some people argued that Pancasila is similar to the covenant of the prophet Muhammad with diverse religious community in Madinah to live and

${ }^{7}$ The drafting team consists of nine members. They are Sukarno, Mohammad Hatta, A.A. Maramis, Abikoesno Tjokrosoejoso, Abdul Kahar Muzakir, Agus Salim, Achmad Subardjo, Wahid Hasyim, and Muhammad Yamin. 
protect each other in religiously plural society. This covenant is named the Madinah Charter (Mithäq al-Madinah) or the Constitution of Medina (Dustür al-Madinah) or the Șahifat al-Madinah. It is an agreement made by the prophet Muhammad shortly after his arrival at Medina (then known as Yathrib) in $622 \mathrm{CE}$ or $1 \mathrm{H}$. There are some interesting points on that archaic document. First, Islam and Muhammad were not placed in divine status above other religions or communities. Second, all religions and beliefs, including indigenous belief systems ("pagan"), were fully accepted as members of the "state" and treated equally before the law. There is no supremacy and favoritism to Islam. Third, the term umma in this document is not exclusively understood as Muslim community or "nation of Islam", but it refers to all tribes and groups in the charter, including Jewish people. This is different from the meaning of umma in our contemporary which often understood as "community of God" or "Muslim people" or "theocratic community, instituted by God to supplant the traditional kinship-based tribes [qaum]". ${ }^{8}$

To convince other Muslims who are still reluctant to accept Pancasila or those still struggle to return to Jakarta Charter or even those who constitutionally tried to reinsert the seven-deleted words from the first pillar, some Muslim scholars such as Ahmad Syafii Maarif have tried to convince their co-religious brothers that the first pillar of Pancasila is no other than Islamic doctrine of tauhid (oneness of god). Therefore, it does not deviate from Islam or against the teachings of Islam. In some sense, Pancasila can be seen as a "contemporary Medina Charter" for Indonesian people. It was formed during the time of Revolution by a number of people representing diverse religious and ethnic background

${ }^{8}$ R. Stephen Humphreys, Islamic History: a Framework for Inquiry, London: I B Tauris, 1999, 92.

9 Ahmad Syafii Maarif, Islam dan Pancasila Sebagai Dasar Dasar Negara: Studi Tentang Perdebatan Dalam Konstituante, Bandung: Mizan, 2017. 
and also competing political inclinations. However, they agreed with a common term to make Indonesia based on Pancasila. It does not give privilege and favouritism to certain religion and ethnicity, but all people must believe in "One and Only God" (Ketuhanan Yang Maha Esa).

Pancasila, as national ideology, has been supported by various Muslim organizations, including Muhammadiyah. During the Congress in Makassar in 2015, Muhammadiyah reemphasized its position on Pancasila. It is summarized in the declaration of "Negara Pancasila sebagai Dār al-Āhdi wa al-Shahādah" (Pancasila State as the Abode of Covenant and the Space of Testimony). For Muhammadiyah, this NKRI (United Nation of Republic of Indonesia) or this Pancasila State is "founded based on a noble national philosophy and in line with Islamic teachings" and all pillars of Pancasila are in essence "in harmony with the values of Islamic teachings". Pancasila, the result of Indonesian consensus, according to Din Syamsuddin, former chairman of Muhammadiyah, "is a common platform and common denominator of Indonesia that can accommodate the shared values of various religions to guarantee the life of the people in national unity". ${ }^{10}$

\section{Pancasila and state-created religions}

In Indonesian politics, as discussed in the previous part of this article, Pancasila is a consensus agreed upon by religiously diverse people of Indonesia immediately before the independence of this country. As a consensus, certainly people could not achieve their highest goals as individual or group. They had to compromise their ideals in order to find common ground to live and work together. For Indonesia, particularly during the the early stages after the independence, Pancasila provided

${ }^{10}$ Hasnan Bachtiar, "Dār al-'Ahd wa al-Shahādah: Muhammadiyah's Contemporary Ijtihād of Siyar and Pancasila”, MA Thesis, College of Arts and Social Sciences, The Australian National University, 2018, 36-37. 
a common philosophy for Indonesian people regardless their religious, ethnicity or any other primordial backgrounds.

What they did not expect or aware of at that stage was the fact that the first pillar of Pancasila, Ketuhanan yang maha esa, does not only make Indonesia a religious state, instead of secular or Islamic one, but more than that it has defined Indonesia clearly as a religiously monotheistic state. Furthermore, although Indonesian people have diverse religious affiliation, the term yang maha esa (the one and only) seems to indicate a theological bias of dominant religious groups, namely Islam and Christianity, in politics during the time of the invention of Pancasila. Even within Muslim and Christian community themselves, as shown in the works of scholars and proponent of these religions, the term yang maha esa has been understood and interpreted differently based on their theological inclination. Sita Hidayah has listed a number of translation of Ketuhanan yang maha esa used by scholars. Among them are "Belief in God", "The Belief in One God", "the Belief in One Supreme God", "the Belief in Oneness of God," "The Belief in the One and Only God", "the Belief in the Divine Omnipotence", "Belief in All-embracing God", "the Belief in One Divine Lordship", "The Unity of God", and "A Supreme Godhead"."11

In the context of religious minority, this term seems to exclude religions that do not belong to the category of monotheistic religions such as Buddhism (often perceived as non-theistic religion) and Hinduism (often seen as polytheistic religion). Therefore, although Pancasila has been hailed as one of the main foundations for guaranteeing religious freedom, the wording of its first pillar contains elements that go against the principles of religious freedom or, to be more precise, limit the scope of religious freedom in Indonesia.

\footnotetext{
${ }^{11}$ Sita Hidayah, “Translating 'Ketuhanan Yang Maha Esa”..., 239-240.
} 


\section{Hinduism and Buddhism: route to become official religions}

From early historical record of religiosity in Indonesia, it was only three religions considered as "recognized" one and have certain department or directorate in the Ministry of Religion. They are Islam, Christianity, and Catholicism. Although Hinduism and Buddhism have longer history in this country, they were not recognized yet as part of official religions because they are seen as not fit enough with the concept of yang maha esa as emboldened in the first pillar of Pancasila.

Hinduism and Buddhism started to be recognized as two additional official religions in 1958 after modifying their theological beliefs in accordance with the first pillar of Pancasila, i.e. changing from polytheistic and non-theistic religions into monotheistic ones. The name of Indonesian Hindu's "one and only" God, i.e. Sang Hyang Widi Wasa, is not known in Hinduistic theological concept in India, the country of origin of Hinduism. Monotheistic Hinduism and believing in one and only god is a unique and distinctive of theological concept of Indonesian Hinduism or commonly called Parisada Hindu Dharma. ${ }^{12}$ This religion must comply with the first pillar of Pancasila in order to be recognized and become official religion in this religiously monotheistic state.

Buddhism also had the same experience, modifying religious doctrines in order to comply with the demand of the state and to be recognized as an official religion. As a non-theistic religion, the concept of God in Buddhism is not as concrete or clear as other religions. Leo Suryadinata

12 Regarding Hindu's conception of God, June McDaniel summarizes as follows: "shamanic or folk Hinduism (emphasizing animism and nature deities), Vedic Hinduism (polytheistic), Vedanta (monistic), Yoga (non-theistic or monistic, sometimes dualistic), Dharma (polytheistic), and Bhakti (usually henotheistic, with a high god over minor gods, and sometimes monotheistic, with other gods as emanations or manifestations)". See June McDaniel, "Agama Hindu Dharma Indonesia as a New Religious Movement: Hinduism recreated in the image of Islam," Nova Religio: The Journal of Alternative and Emergent Religions, Vol. 14 No. 1 (2010), 94. 
elaborates nicely about the concept of God in Buddhism by quoting the debate between Bhikkhu Narada of Sri Lanka and Bhikkhu Ashin Ashin Jinarakkhita of Indonesia as follows: "Bhikkhu Narada of Sri Lanka strongly disagreed with Bhikkhu Ashin, arguing that 'there is no god in Buddhism'. He refused to accept Bhikkhs's Ashin's 'theistic Budhhism', which is common in the Mahayana of Indonesia and Nepal". ${ }^{13}$ However, because of the demand of Indonesian government Indonesian Buddhism declared Sang Hyang Adhi Buddha as their one and only God. This name is taken from the tenth century old Javanese text, called Sang Hyan Kamahayanikan. The role of Bhikkhu Ashin Jinarakkhita was very significant in defining and constructing this theistic Buddhism.

More detail story on the controversy of Adi Buddha is narrated by Karel Steenbrink. Responding to this unique and distinctive theological concept of Indonesian Buddhism, a "Sri Lankan monk Narada, who had visited Indonesia in 1934 and later again in 1959 and 1969... wrote quite often to Parwati, a secretary to Jinarakkhita, and urged her: "Please, tell your teacher that there is no God in Buddhism". Jinarakkhita's reaction was that this could be true for Ceylonese Buddhism, but Indonesian Buddhism cherished a distinct flavour of several blends of Buddhism and would not practise its religion without the concept of a supreme divinity". ${ }^{14}$

\section{Confucianism and indigenous religions}

The fate of Confucianism is interesting. This ancestral belief was perceived as religion during Sukarno administration and even included in one of six recognized religions as in the law no. 1/PNPS/1965. During

${ }^{13}$ See Leo Suryadinata, The Culture of the Chinese Minority in Indonesia, Singapore: Times Books International, 1997, 178.

${ }^{14}$ Karel A. Steenbrink, "Buddhism in Muslim Indonesia," Studia Islamika, Vol. 20 No. 1 (2013), 11. 
Suharto administration, Confucianism was initially recognized by the government, but then, using the Presidential Instruction No. 14 in 1967, it was banned as religion and the religious activities related to this belief were forbidden. During the time of Abdurrahman Wahid's presidency, the prohibition of Confucianism was revoked with the issuance of the presidential decree No. 6 in 2000 and this religion has the same rights as other five official religions in Indonesia. ${ }^{15}$

As elaborated by Leo Suryadinata, the reason why the government withdraw its recognition to Confucianism is interesting.

One explanation is that initially the military-led government needed support from various religious groups in its struggle against the communists, who were presumably atheists. However, the support of Matakin [Supreme Council of Indonesian Confucian Religion] was considered to be in contradiction to the government assimilationist policy. The second possible explanation is that if Confucianism is officially recognized as a religion, it might lead to the eventual recognition of Chinese religious rights: the Confucian religion cold be taught in the school as a legitimate religious subject, Confucian holidays (Chinese holidays) would be recognized as Indonesian holidays. This would be against the assimilationist goal prescribed by the Suharto government. ${ }^{16}$

Before it was banned in 1967, to be recognized as a state religion, Confucianism also must follow the state-mandated theology, i.e. becoming monotheistic religion by believing one and only god. In its country of origin, Confucianism is a belief system, not considered as a religion, that does not clearly declare the name of god for this belief. Because the conception of one and only god is a requirement in Indonesia, followers of Confucianism then "appointed" Thian as their one and only god.

\footnotetext{
${ }^{15}$ Ahmad Najib Burhani, Menemani Minoritas: Paradigma islam tentang Keberpihakan dan Pembelaan kepada yang Lemah, Jakarta: Gramedia Pustaka Utama, 2019, 41-43.

${ }^{16}$ Leo Suryadinata, The Culture of the Chinese Minority in Indonesia..., 164-165.
} 
It is not only the conception of deities that must abide the regulation from religiously monotheistic state of Indonesia, the conception of religion in this country is also strongly influenced by monotheistic religion of Islam and Christianity. Although not stated in the constitution or in Pancasila, but in Indonesian context, what is called religion must have prophet and a holy scripture. Following this "unwritten" rule ${ }^{17}$, Confucianism then appointed Confucius as the prophet of that religion and Buku Yang Empat $(\mathrm{Su} \mathrm{Si})$ as its holy book. The place of congregation for Confucians is called Lithang (Litang, Ceremonial Hall). The priesthood in this religion is classified into three ranks: Haksu, Bunsu, and Kausing. ${ }^{18}$

The "unwritten" definition of religion has far wider consequences other than modification of theological beliefs in Hinduism, Buddhism, and Confucianism. For indigenous or ancestral religions such as Parmalim, Sunda Wiwitan, and Kaharingan, their belief system is not simply ignored as a kind or a system of religion, but the followers of that beliefs are often seen as worshippers of stones or woods which is usually called as animism and dynamism. These belief systems have been preserved as an object of tourism and for a long time these beliefs were under the Ministry of Tourism, not under the Ministry of Religion.

Because of the perception that they are uncivilized and not having

${ }^{17}$ Picard and Madinier mention that the definition of religion can be found in TAP (People's Assembly Resolution) MPR No. 2 in 1960. In her article, Sita Hidayah also refers to this Resolution on the definition of religion. Agama or religion, as defined by this Resolution, must have a holy scripture, a prophet, and affirms the oneness of God. My study of that Resolution, however, does not find the definition of religion there. It is also often stated that the definition of agama can be found in Tap MPR No IV/MPR/1978 that is followed by an Instruction from the Ministry of Religion (Instruksi Menag) No 4 Tahun 1978. My study also does not find the definion of religion there. What is stated in the TAP MPR No. XXVII/MPRS/1966 is the term "diakui" (recognized) for certain religions. See Michel Picard and Rémy Madinier, The Politics of Religion in Indonesia: Syncretism, Orthodoxy, and Religious Contention in Java and Bali, Abingdon, Oxon: Routledge, 2011, 11; Sita Hidayah, "The politics of religion"..., 8 .

${ }^{18}$ Leo Suryadinata, The Culture of the Chinese Minority in Indonesia..., 167. 
religion yet, the followers of ancestral beliefs have become object of mission from mainstream and recognized religions such as Islam, Christianity, Hinduism, and Buddhism. At national level, indigenous beliefs of Indonesia, formally called aliran or penghayat kepercayaan, are now under the Ministry of Education and Culture. The move from the Ministry of Tourism to the Ministry of Education and Culture is often seen as an improvement or a better treatment; not perceiving them as an object of tourism, but as part of the richness of Indonesian culture. However, these beliefs are often seen merely as part of culture in general, not specifically perceived as religions. These beliefs are perceived of preserving Indonesian local wisdoms, but not a comprehensive system of belief and certainly not a complete way of life as provided by religions. Furthermore, some activists of religious freedom accused this move as a way or a trick from dominant religion to bring the followers of indigenous religions to the "right path", i.e. dominant religions. This perception is further justified by the statement in the Law No. 1/PNPS/ 1965 which states: "Towards the believers of Faith, the government is trying to channel them towards a healthy view and towards a belief in One and Only God". 19

\section{Pancasila and religious intolerance}

Besides the impact of the wording of the first pillar of Pancasila towards non-mainstream religions, this pillar has also inspired the government to intervene religious affairs by becoming a main source for regulations on religion, including the controversial Law on the Defamation of Religion Law, also known as Blasphemy Law, no. 1/PNPS/1965 and religious bylaws in a number of districts and provinces in Indonesia. Similar to the way the first pillar creates boundaries of the acceptable conception

${ }^{19}$ Trisno Sutanto, "Diskriminasi terhadap Penghayat: Sampai Kapan?", a paper presented at the seminar on "Pluralitas dan Minoritas dalam Konteks Kebangsaan", Jakarta, LIPI, 1 December 2016. 
of deity in the framework Indonesian religiosity, the politics behind the drafting of this pillar, i.e. giving favorite to dominant religious groups and compromising religious rights of religious minorities for the sake of harmony and unity, influences or inspires similar type of regulations on religion. The bias of religious regulations can be said as indirectly correlate to the first pillar. What can be inferred from the first pillar in this context is to allow favoritism and inclination to certain groups.

This kind of favoritism has now become a mental construct or frame of thought among Indonesian people. In Papua and West Papua provinces, where Christianity is a dominant religion, there were efforts by religious activists there to implement favoritism to Christianity by making kota Injili (City of Bible) and making local regulations that more incline to support Christian mission. ${ }^{20}$ For political and diplomatic goal, i.e. Helsinki agreement, Aceh province has even become an "Islamic province" that implemented shari'a law, including wilayah hisbah or religious police. Wearing hijab becomes mandatory in that province, regardless religious affiliation of people there. Hudud is partly implemented for those who violates Islamic law. After Aceh and Papua, some Hindu people in Bali have tried to follow the step of these two provinces by proposing regulation that give favoritism to Hinduism. ${ }^{21}$

Even in the provinces dominated by Muslims, such as East Java, certain sect or denomination of Islam have tried to create regulations that give favoritism to the majority. Situbondo district, for instance, has called itself as a city of shalawat nariyah. What does it mean? Shalawat is a tradition specifically within Nahdlatul Ulama community. Although

${ }^{20}$ See "Upaya menjadikan Manokwari sebagai 'Kota Injil' pertama di Indonesia”. https://www.bbc.com/indonesia/indonesia-40695899; "Polemik Perda Manokwari Kota Injil”, https://tirto.id/polemik-perda-manokwari-kota-injil-ddsi (Accessed, 9 May 2019).

${ }^{21}$ See "Perda Desa Adat, Menyayomi Pengawal Budaya Bali", http://www.balipost.com/ news/2019/04/04/72291/Perda-Desa-Adat,Mengayomi-Pengawal...html (Accessed, 9 May 2019). 
it is accepted by other Muslim groups, such as Muhammadiyah, but it is more identical with NU culture. Creating a slogan for a city based on certain religious inclination, let alone a specific group, seems to overlook other religious community that live together in the area. Furthermore, the slogan does not only call this city as kota shalawat, but kota shalawat nariyah which refers to a more specific community within Islam and within Nahdlatul Ulama, i.e. the traditionalist of the NU of East Java. ${ }^{22}$

In short, the first pillar of Pancasila has influenced and nurtured a mental construct and frame of thought of favoritism and, in some cases, sectarianism among religious people. In order to appease the majority, for instance, compromising religious rights of minority groups is often taken by government in its discretions. The philosophy behind this one is "harmony over religious freedom".

Harmony and religious freedom are two key terms in the debate about religiosity in Indonesia. Most of the people agree with religious harmony, including by limiting religious rights for the sake of social order. Religious freedom is a term hated by a number of religious groups. A number of people, including in the Muhammadiyah and the NU, do not see the issue of Ahmadiyya is part of religious freedom. They see that as a case of defamation of Islam. As stated by Amin Djamaluddin, Ahmadiyya is not and cannot be included in the issue of religious freedom. This view finds its echo in Muslim communities in Indonesia, including two largest Muslim organizations, NU and Muhammadiyah. ${ }^{23}$ The dream of harmony as expected by activists of religious freedom seems to be different from the illusion of harmony of religious mainstream. For the latter, the

22 See "Di Bumi Shalawat Nariyah, FKS Situbondo Berpacu Kembangkan Desa Sehat", https://www.timesindonesia.co.id/read/176931/20180717/145138/di-bumi-shalawatnariyah-fks-situbondo-berpacu-kembangkan-desa-sehat/products.html (Accessed, 9 May 2019).

${ }^{23}$ Ahmad Najib Burhani, "Fundamentalism and Religious Dissent"..., 145-164. 
harmony that they want to create is based on restriction and cutting off any differences. For the former, the harmony is based on co-existence and mutual respect in a plural society. The term is the same, but the meaning and the way to implement it is different.

The case of prohibition of peringatan 'Ashura organized by Shi'ite community in Bogor in 2015 is an example of compromising religious rights of minority group in order to appease the majority under the rhetoric of maintaining social order. ${ }^{24}$ Also, as reflected in the judicial review of the Blasphemy Law No. 1/PNPS/1965, the Constitutional Court at the end found that this law is still needed to maintain order and religious harmony in Indonesia.

\section{Conclusion}

The root of religious intolerance can be found in Indonesian constitution and its ideology of the state, Pancasila. The discriminative treatment towards religious minorities has embedded there since the establishment of this country. The first pillar of Pancasila Ketuhanan yang maha esa, stated two times in the constitution; in the preamble and in the article 29, defines Indonesia as a religiously monotheistic state, not a secular or Islamic state. In order to be recognized as official religions in this religiously monotheistic state, polytheistic and non-theistic must modify their theological beliefs.

This philosophy has been implemented towards religious minorities such as Hinduism, Buddhism, and Confucianism. Sadly, this modification has not worked yet in the context of indigenous religions. They are often seen merely as belief system, not religion. And they have become a subject of mission or an object of tourism. However, changing the first pillar of Pancasila is something difficult even to imagine it. Changing

\footnotetext{
${ }^{24}$ During my interview with the mayor of Bogor, Bima Arya, in his office on ..., he said that he issued the decree in order to avoid chaos because some people threaten to take the law into their own hands if the government did not prohibit the event.
} 
Pancasila is like changing the state in total. The existence of the holes in Pancasila, perhaps for now, just for the awareness of people, particularly in academic discourse.

\section{Bibliography}

Atkinson, Jane Monnig, "Religions in dialogue: the construction of an Indonesian minority religion", in Indonesian religions in transition, Rita Smith Kipp and Susan Rodgers (eds.). Tucson: Arizona State University, 1987: 171-86.

Bachtiar, Hasnan, Dār al-'Ahd wa al-Shahādah: Muhammadiyah's Contemporary Ijtihād of Siyar and Pancasila”, MA Thesis, College of Arts and Social Sciences, The Australian National University, 2018.

Bagir, Zainal Abidin, "Defamation of Religion Law in Post-Reformasi Indonesia: Is Revision Possible?", Australian Journal of Asian Law, Vol. 13, No. 2 (2013): 1-16.

Bagir, Zainal Abidin, "Advocacy for Religious Freedom in Democratizing Indonesia", The Review of Faith $\mathcal{E}$ International Affairs, Vol. 12, No. 4 (2014): 27-39.

Bertrand, Jacques. Nationalism and ethnic conflict in Indonesia. Cambridge, UK: Cambridge University Press, 2004.

Burhani, Ahmad Najib. Menemani Minoritas: Paradigma islam tentang Keberpihakan dan Pembelaan kepada yang Lemah. Jakarta: Gramedia Pustaka Utama, 2019.

Burhani, Ahmad Najib, "Fundamentalism and Religious Dissent: the LPPI's Mission to Eradicate the Ahmadiyya in Indonesia”, Indonesia and the Malay World. Vol. 44, No. 129 (2016): 145-164.

Bush, Robin and Budhy Munawar-Rachman, "NU and Muhammadiyah: Majority Views on Religious Minorities in Indonesia", in Johan Saravanamuttu and Bernhard Platzdasch (eds.). Religious diversity in Muslim-majority states in Southeast Asia: Areas of Toleration and Conflict. Singapore: ISEAS, 2014: 16-50.

Colbran, Nicola. "Realities and Challenges in Realising Freedom of Religion or Belief in Indonesia", The International Journal of Human 
Rights, Vol. 14, No. 5 (2010): 678-704.

Colbran, Nicola, "Indigenous Peoples in Indonesia: At Risk of

Disappearing as Distinct Peoples in the Rush for Biofuel?", International Journal on Minority and Group Rights, Vol. 18, No. 1 (2011): 63-92.

Crouch, Melissa, "Judicial Review and Religious Freedom: The Case of Indonesian Ahmadis”, Sydney Law Review, Vol. 34, No. 3 (2012): 545-572.

Darmaputra, Eka, "Pancasila and the Search for Identity and Modernity in Indonesian Society: A Cultural and Ethical Analysis", Ph.D. Diss - Boston College, 1982.

Ekowati, Wilis Rengganiasih Endah, "Bhikkhu Ashin Jinarakkhita's Interpreting and Translating Buddhism in Indonesian Cultural and Political Contexts," in Teaching Dhamma in new lands. Academic Papers presented at the 2nd IABU Conference Mahachulalongkornrajavidyalaya University, Main Campus Wang Noi, Ayutthaya, Thailand, 2012.

Elson, R.E., "Two Failed Attempts to Islamize the Indonesian Constitution”, Sojourn: Journal of Social in Southeast Asia, Vol. 28, No. 3 (2013): 379-437.

Feener, R. Michael, "Official Religions, State Secularisms, and the Structures of Religious Pluralism," in Proselytizing and the Limits of Religious Pluralism in Contemporary Asia, Juliana Finucane and R. Michael Feener (eds.). Singapore: Springer, 2014: 1-16.

Hasani, Ismail and Bonar Tigor Naipospos. Mengatur kehidupan beragama; Menjamin kebebasan? Urgensi kebutuhan RUU Jaminan Kebebasan Beragama/Berkeyakinan. Jakarta: Pustaka Masyarakat Setara, 2011.

Hatta, Mohammad. Pengertian Pancasila: pidato peringatan lahirnya Pancasila, tanggal 1 Juni 1977 di Gedung Kebangkitan Nasional, Jakarta. Jakarta: Idayu Press, 1977.

Hidayah, Sita, "The Politics of Religion: The Invention of "Agama" in Indonesia”, Kawistara, Vol. 2, No. 2 (2012): 121-139.

Hidayah, Sita, “Translating 'Ketuhanan Yang Maha Esa': An Amenable 
Religious Ideology", in Pancasila's Contemporary Appeal: Re-legitimizing Indonesia's Founding Ethos. Thomas J. Conners, et. al. (eds.). Yogyakarta: Sanata Dharma University Press, 2010: 239-254.

Howell, Julia, "Muslims, the New Age and Marginal Religions in Indonesia: Changing Meanings of Religious Pluralism", Social Compass, Vol. 52, No. 4 (2005): 473-493.

Ichwan, Moch Nur, "Secularism, Islam and Pancasila: Political debates on the basis of the state in Indonesia," Bulletin of the Nanzan Center for Asia-Pacific Studies, Vol. 6 (2011): 1-43

Intan, Benyamin Fleming, "Public religion' and the Pancasila-based state of Indonesia: a normative argument within a Christian-Muslim dialogue (1945-1998)”, Ph.D. Diss., Boston College, 2004.

Ismail, Faisal, "Islam, Politics and Ideology in Indonesia: A Study of the Process of Muslim Acceptance of the Pancasila”, Ph.D. Diss., McGill University, 1995.

Kipp, Rita Smith, and Susan Rodgers. Indonesian Religions in Transition. Tuscon, Arizona: University of Arizona Press, 1987.

Klinken, Gerry Van. Communal Violence and Democratization in Indonesia Small Town Wars. London: Routledge, 2009.

Latif, Yudi. Negara Paripurna: Historisitas, Rasionalitas, dan Aktualitas Pancasila. Jakarta: Gramedia Pustaka Utama, 2011.

Maarif, Ahmad Syafii. Islam Dan Pancasila Sebagai Dasar Dasar Negara: Studi Tentang Perdebatan Dalam Konstituante. Bandung: Mizan, 2017. Menchik, J., "Productive Intolerance: Godly Nationalism in Indonesia", Comparative Studies in Society and History, Vol. 56, No. 3 (2014): 591-621. McCoy, Mary E., "Purifying Islam in Post-Authoritarian Indonesia: Corporatist Metaphors and the Rise of Religious Intolerance", Rhetoric $\mathcal{E}$ Public Affairs, Vol. 16, No. 2 (2013): 275-315.

McDaniel, June, "Agama Hindu Dharma Indonesia as a New Religious Movement: Hinduism Recreated in the Image of Islam," Nova Religio: The Journal of Alternative and Emergent Religions, Vol. 14, No. 1 (2010): 93-111.

Morfit, Michael, "Pancasila: The Indonesian State Ideology According to 
the New Order Government," Asian Survey, Vol. 21, No. 8 (1981): 838-851.

Picard, Michel, and Rémy Madinier. The Politics of Religion in Indonesia: Syncretism, Orthodoxy, and Religious Contention in Java and Bali. Abingdon, Oxon: Routledge, 2011.

Prawiranegara, Sjafruddin, "Pancasila as the Sole Foundation," Indonesia, Vol. 38 (1984): 74-83.

Purdy, Susan Selden, "Legitimation of power and authority in a pluralistic state: Pancasila andcivil religion in Indonesia”, Ph.D. Diss., Columbia University, 1984.

Putra, Edi Ramawijaya, "Buddhism in Indonesia: The current issues of development of Buddhism and modern Muslim," in Teaching Dhamma in new lands. Academic Papers presented at the 2nd IABU Conference Mahachulalongkornrajavidyalaya University, Main Campus Wang Noi, Ayutthaya, Thailand, 2012.

Ropi, Ismatu, "Ketuhanan Yang Maha Esa, the State and the Politics of Religious (In)Tolerance: Understanding Contemporary Religious Life through Past Debates on the State-Religion Relationship," in Religion, Law and Intolerance in Indonesia. Tim Lindsey and Helen Pausacher (eds.). New York: Roudledge, 2016: 132-157.

Ropi, Ismatu, "The Politics of Regulating Religion: State, Civil Society and the Quest for Religious Freedom in Modern Indonesia”, PhD Theses,Australian National University, 2013.

Ropi, Ismatu, "Defending religious freedom in Indonesia: Muslims, nonMuslims and legislation on houses of worship," in Islam and the question of freedom: Critical voices from Muslim communities. Benjamin MacQueen, Kylie Baxter, and Rebecca Barlow (eds.). Victoria: Melbourne University Press, 2008: 73-93.

Sezgin, Yuksel, "Regulation of 'Religion' and the 'Religious': The Politics of Judicialization and Bureaucratization in India and Indonesia," Comparative Studies in Society and History Vol. 56, No. 2 (2014): 448478.

Soedirgo, Jessica, "Informal Networks and Religious Intolerance: How 
Clientelism Incentivizes the Discrimination of the Ahmadiyah in Indonesia”, Citizenship Studies. No. 22, No. 2 (2018): 191-207.

Steenbrink, Karel A., "Buddhism in Muslim Indonesia," Studia Islamika, Vol. 20, No. 1 (2013): 1-34.

Steenbrink, Karel A. "The Pancasila Ideology and an Indonesian Muslim Theology of Religions," in Muslim Perceptions of Other Religions: A Historical Survey. Jacques Waardenburg (ed.). New York: Oxford University Press, 1999: 280-96.

Steenbrink, Karel A. "Muslim-Christian relations in the Pancasila state of Indonesia," The Muslim World, Vol. LXXXVIII, No. 3-4 (1998): 320-352.

Sukarno. Lahirnya Pantjasila: pidato Bung Karno, sekarang P.J.M. Presiden R.I. pada tanggal 1 Djuni 1945 dimuka sidang jang pertama Badan Penjelidik Usaha Persiapan Kemerdekaan. Jakarta: Departemen Penerangan R.I. Penerbitan Khusus nomor 153, 1947.

Suryadinata, Leo, "State and Minority Religions in Contemporary Indonesia: Recent Government Policy towards Confucianism, Tridharma and Buddhism ," in Nation-state, identity, and religion in Southeast Asia. Tsuneo Ayabe (ed.). Singapore: Singapore Society of Asian Studies, 1998: 5-24.

Leo Suryadinata. The Culture of the Chinese Minority in Indonesia. Singapore: Times Books International, 1997.

Trisno Sutanto, "Diskriminasi terhadap Penghayat: Sampai Kapan?”, a paper presented at the seminar on "Pluralitas dan Minoritas dalam Konteks Kebangsaan”, Jakarta, LIPI, 1 December 2016.

Sutanto, Trisno S., "Reclaiming Pancasila", The Jakarta Globe, 30 June 2009.

Titaley, John A., "A Sociohistorical Analysis of the Pancasila as Indonesia's State Ideology: in the Light of the Royal Ideology in the Davidic State", Thesis (Ph.D.), Graduate Theological Union, 1991.

Varshney, Ashutosh (ed.). Collective Violence in Indonesia. Boulder: Lynne Rienner Publishers, 2010.

Wahid, Abdurrahman, "Indonesia's Mild Secularism”, SAIS Review, Vol. 
IJIMS: Indonesian Journal of Islam and Muslim Societies, Volume 9, Number 1, June 2019: 111-134

21, No. 2 (2001): 25-28.

Ward, Ken, "Soeharto's Javanese Pancasila," in Soeharto's New Order and Its Legacy Essays in honour of Harold Crouch, Edward Aspinall and Greg Fealy (eds.). Canberra: ANU E Press, 2010: 27-37. 